\title{
Effect of Organic Manures on Nutrient Uptake and Seed Quality of Sesame
}

\author{
Paul Anguria ${ }^{1}$, George N. Chemining'wa ${ }^{2}$, Richard N. Onwonga ${ }^{3} \&$ Michael A. Ugen ${ }^{1}$ \\ ${ }^{1}$ National Semi Arid Resources Research Institute (NaSARRI), Soroti, Uganda \\ ${ }^{2}$ Department of Plant Science and Crop Protection, University of Nairobi, Nairobi, Kenya \\ ${ }^{3}$ Department of Land Resource Management and Agricultural Technology, University of Nairobi, Nairobi, \\ Kenya \\ Correspondence: Paul Anguria, National Semi Arid Resources Research Institute, Serere, P.O. Box 56, Soroti, \\ Uganda. E-mail: paulanguria@yahoo.com
}

Received: April 12, 2017

doi:10.5539/jas.v9n7p135

\begin{abstract}
The influence of organic manures in nutrient uptake and seed quality of sesame is not fully known. In this context, a study was conducted in northeastern Uganda in 2013 and 2014 short rains, and 2014 long rains to investigate the effect of organic manures on nutrient uptake and seed quality of sesame. The experiment was laid out in randomized complete block design with three replications. The treatments comprised: control, 4 crop residues, 2 animal manures and combinations of 2 animal manures and 4 crop residues all applied at two rates of 3 and $6 \mathrm{t} / \mathrm{ha}$. Poultry manure plus finger millet husks $(6 \mathrm{t} / \mathrm{ha})$ produced significantly the highest seed protein content (48.23\%) and uptake of $\mathrm{N}(4.84 \%), \mathrm{P}(0.66 \%)$ and $\mathrm{K}(1.86 \%)$ by sesame at 4 weeks after emergence. Poultry manure plus cowpea husks $(6 \mathrm{t} / \mathrm{ha})$ and poultry manure plus groundnut shells $(3 \mathrm{t} / \mathrm{ha})$ produced the highest total ash (8.71\%) and sesame seed oil content (67.95\%), respectively. The crop residue effect on seed crude protein content, seed total ash and seed oil content occurred in the order of finger millet $>$ cowpea $>$ groundnut $>$ sorghum, finger millet $>$ cowpea $>$ sorghum $>$ groundnut and groundnut $>$ sorghum $>$ cowpea $>$ finger millet, respectively. This study has demonstrated that finger millet husks and groundnut shells effectively enhance protein and oil content of sesame than other crop residues, respectively. Poultry manure plus finger millet husks ( $3 \mathrm{t} / \mathrm{ha}$ ) enhances sesame seed protein content than other treatments.
\end{abstract}

Keywords: crude protein, finger millet, harvest index, seed oil and total ash

\section{Introduction}

Sesame (Sesamum inducum L.) is cultivated mainly by smallholder farmers in the semi-arid areas of north east Uganda both as a cash and food security crop. Sesame seeds are used either decorticated or whole in form of baked sweetened sesame bars or cubes and milled to get high grade edible oil or an oily paste (Anyanga et al., 2001; Bedigian, 2003). Sesame seeds contain high quality oil in the range of $50-60 \%$ and are rich in calcium $(35 \%)$ and proteins (methionine and tryptophan) (34\%-50\%) (Baydar et al., 1999; Morris., 2002). Consequently, it is suitable for use as a food crop in starch staple diets of most small holder farmers in sub-Saharan Africa. After oil extraction from sesame seeds, the residual meal is used as a constituent of livestock feeds (Munyua et al., 2013).

Owing to its high oil and nutrient content, sesame has a great potential to meet food and nutrition security as well as generate household income and earn foreign exchange for most countries in sub-Saharan Africa. However, farmers in these regions are resource poor and heavily depend on rain-fed crop production systems and natural soil fertility for crop production (Ibeawuchi et al., 2009). Unfortunately, rainfall is insufficient, unpredictable and poorly distributed. This coupled with low soil nutrient status has resulted in persistently low sesame crop yields $(673 \mathrm{~kg} / \mathrm{ha}$ ) at farmers' fields compared to a potential yield of $2250 \mathrm{~kg} / \mathrm{ha}$ (Anyanga et al., 2003; Munyua et al., 2013). Sesame crop harvests are too low to provide adequate quantities of the crop to meet both urgent household food needs and generate enough income to buy inorganic fertilizers that are expensive and out of reach of most resource poor smallholder farmers. Consequently, there is accelerated soil infertility.

Soils in north east Uganda are deficient in nitrogen, phosphorus and potassium required for proper crop growth (Tenywa et al., 1999). Application of organic manure on these soils would most likely improve their quality 
(Sanchez et al., 2002). Organic materials are a major source of organic matter and plant nutrients. Incorporating organic materials into soil results in improved soil physical attributes namely: soil structure, soil aggregate stability, water holding capacity, soil drainage, soil aeration and root penetration and soil chemical attributes namely: soil nutrient content and composition and soil pH (Craswell et al., 2001; Murphy., 2015). Application of organic manures on sesame in form of crop residues and animal manure would most likely improve its yields and seed quality (Anyanga et al., 2001; Morris, 2002; Bedigian, 2003). However, there is inadequate information on the use and effect of crop residues and animal manure on nutrient uptake and quality of sesame. Therefore, a study was conducted to assess the effect of crop residues and animal manures on nutrient uptake and quality of sesame.

\section{Materials and Methods}

\subsection{Description of Study Site}

\subsubsection{Weather and Altitude}

This study was conducted at the National Semi-Arid Resources Research Institute (NaSARRI), Serere, Uganda. NaSARRI is located at $0^{\circ} 32^{\prime} \mathrm{N}$ and $35^{\circ} 27^{\prime} \mathrm{E}$ at 1128 meters above sea level. The site experiences an average annual minimum temperature of $17.9^{\circ} \mathrm{C}$ and a maximum temperature of $29.4{ }^{\circ} \mathrm{C}$. It receives an average annual rainfall of $1000 \mathrm{~mm}$ with a bimodal distribution. The relative humidity ranges between $72 \%$ and $84 \%$. January, February, June and July are driest months with very little precipitation. However, the months of March, May, August and November are generally the wettest.

\subsubsection{Soil Properties}

The soils at the experimental site are mainly sandy with low organic matter content and are classified as petric plinthosols although traces of gleysols and vertisols also exist (Aniku, 2001). These soils were predominantly sandy silt loams with a $\mathrm{pH}$ ranging between 5.10 and 5.40. Calcium level was $3.13 \mathrm{me} / 100 \mathrm{~g}$, while organic carbon was in the range of $1.8 \%$ and $2.3 \%$. Phosphorus and $\mathrm{Na}$ levels were $9.74 \mathrm{ppm}$ and $0.48 \mathrm{me} / 100 \mathrm{~g}$, respectively. Magnesium level was at $0.71 \mathrm{me} / 100 \mathrm{~g}$, while $\mathrm{K}$ level is at $0.67 \mathrm{me} / 100 \mathrm{~g}$.

\subsection{Treatments, Experimental Design and Crop Husbandry}

The treatments comprised: control (no amendments), animal manures (poultry and cow, each at two rates of 3 and $6 \mathrm{t} / \mathrm{ha}$ ), crop residues (millet, sorghum, cowpea and groundnuts, each at two rates of 3 and $6 \mathrm{t} / \mathrm{ha}$ ) and combinations of animal manure and crop residues, each at two rates of 3 and $6 \mathrm{t} / \mathrm{ha}$. The treatments were laid out in a randomized complete block design and replicated three times. Animal manure and crop residues were mixed in equal proportions of $1: 1 ; 1$ part of animal manure to 1 part of crop residue. Both crop residues and animal manure were analyzed for chemical elements before they were applied on experimental plots. The crop residues of finger millet, sorghum, cowpea and groundnut were got from seremi 2, seso 3, secow 2 and serenut 2 crop residues, respectively. These crop residues were incubated in pits for 1 month prior to their application, while poultry and cattle manures were applied when properly decomposed. Each experimental plot measured $4 \mathrm{~m} \times 4$ $\mathrm{m}$ with a path of $1 \mathrm{~m}$ separating plots. Sesim II variety was used in this study. It is highly branching with an average height of $100 \mathrm{~cm}$ and a maturity period of 90 days. Six seeds were planted per hill at inter and intra row spacing of $30 \mathrm{~cm}$ and $15 \mathrm{~cm}$ respectively. The crop was then thinned to one plant per hill at three weeks after planting. The crop was hand weeded three times before it was harvested.

\subsection{Data Recording}

\subsubsection{Leaf Mineral Content Analysis}

Sesame leaves were analyzed for N, P and K contents at four weeks after emergence and $75 \%$ flowering. Sesame leaves were sampled from ten plants and oven dried at $60{ }^{\circ} \mathrm{C}$ to a constant weight, ground and stored in small polythene bags. Nitrogen in sesame leaves was determined using the Kjeldahl method, available phosphorus was determined using the Mehlich method and potassium was determined using the Flame photometry method (Nelson \& Sommers, 2010)

\subsubsection{Sesame Seed Nutritional Quality}

Seed oil content was determined using the Soxhlet method (AOAC, 1990). Crude Protein and total ash content in sesame seeds were determined using Kjeldahl and dry ashing methods, respectively. The conversion factor of 6.25 was used to convert Kjeldahl nitrogen to (\%) protein (Nelson et al., 2010)

\subsection{Data Analysis}

Collected data were subjected to analysis of variance (ANOVA) using Genstat statistical package $13^{\text {th }}$ edition, 2013. The means were compared using the least significant difference (LSD) test at $\mathrm{P} \leq 0.05$. 


\section{Results}

3.1 Effect of Crop Residues, Animal Manure and Their Combination on N, P and K Content of Sesame Leaves at 4 Weeks after Emergence and at 75\% Flowering

Application of crop residues and animal manure singly and in combination significantly $(\mathrm{P} \leq 0.05)$ affected $\mathrm{N}$ and $\mathrm{K}$ concentration in sesame leaves at both 4 weeks after emergence and $75 \%$ flowering, but only affected $\mathrm{P}$ concentration in sesame leaves at $75 \%$ flowering (Tables $1 \mathrm{a}, 1 \mathrm{~b}$ and $1 \mathrm{c})$. Finger millet husks $(6 \mathrm{t} / \mathrm{ha})$ produced significantly $(\mathrm{P} \leq 0.05)$ higher concentration of $\mathrm{N}(3.14$ to $4.44 \%), \mathrm{P}(0.26$ to $0.64 \%)$ and $\mathrm{K}(0.18$ to $1.84 \%)$ in sesame leaves at 4 weeks after emergence and $75 \%$ flowering than other crop residues and $3 \mathrm{t} / \mathrm{ha}$ of millet husks across seasons (Table 1a). Poultry manure $(6 \mathrm{t} / \mathrm{ha})$ produced significantly $(\mathrm{P} \leq 0.05)$ higher concentrations of $\mathrm{N}$ ( 3.42 to $4.66 \%), \mathrm{P}(0.25$ to $0.48 \%)$ and $\mathrm{K}(0.19$ to $1.81 \%)$ in sesame leaves at both 4 weeks after emergence and $75 \%$ flowering than cattle manure and poultry manure $(3 \mathrm{t} / \mathrm{ha})$ across seasons (Table 1a). Incorporation of poultry manure plus finger millet husks $(6 \mathrm{t} / \mathrm{ha})$ produced significantly $(\mathrm{P} \leq 0.05)$ higher concentration of $\mathrm{N}(3.61$ to $4.84 \%), \mathrm{P}(0.26$ to $0.66 \%)$ and $\mathrm{K}(0.19$ to $1.86 \%)$ in sesame leaves than poultry manure plus finger millet husks ( $3 \mathrm{t} / \mathrm{ha}$ ) and poultry manure plus other crop residues (Table $1 \mathrm{~b}$ ). Application of cattle manure plus finger millet husks $(6 \mathrm{t} / \mathrm{ha})$ produced significantly $(\mathrm{P} \leq 0.05)$ higher concentration of $\mathrm{N}(3.51$ to $4.08 \%)$ and $\mathrm{K}(0.19$ to $1.77 \%$ ) in sesame leaves than cattle manure plus other crop residues and cattle manure plus finger millet husks (3 t/ha) at 4 weeks after emergence and $75 \%$ flowering (Table 1c). Overall, application of poultry manure plus millet husks (6 t/ha) produced the highest concentration of $\mathrm{N}, \mathrm{P}$ and $\mathrm{K}$ in sesame leaves at both 4 weeks after emergence and $75 \%$ flowering (Tables $1 \mathrm{a}, 1 \mathrm{~b}$ and $1 \mathrm{c}$ ). At 75\% flowering, $\mathrm{N}, \mathrm{P}$ and $\mathrm{K}$ concentration in sesame leaves significantly reduced with greater reduction in $\mathrm{K}$ (Tables $1 \mathrm{a}, 1 \mathrm{~b}$ and $1 \mathrm{c}$ ).

Table 1a. Effect of crop residues and animal manure on N, P and $\mathrm{K}$ contents of sesame leaves at 4 weeks after emergence and $75 \%$ flowering

\begin{tabular}{|c|c|c|c|c|c|c|}
\hline \multirow{2}{*}{ Treatments } & \multicolumn{2}{|c|}{ Nitrogen (\%) } & \multicolumn{2}{|c|}{ Phosphorus (\%) } & \multicolumn{2}{|c|}{ Potassium (\%) } \\
\hline & 4 WAE & $75 \%$ flowering & $4 \mathrm{WAE}$ & $75 \%$ flowering & 4 WAE & 75\% Flowering \\
\hline Control & 3.44 & 2.14 & 0.31 & 0.14 & 1.65 & 0.13 \\
\hline \multicolumn{7}{|l|}{ Crop residues } \\
\hline Millet (3 t/ha) & 3.76 & 2.56 & 0.27 & 0.21 & 1.67 & 0.16 \\
\hline Millet (6 t/ha) & 4.44 & 3.14 & 0.64 & 0.26 & 1.84 & 0.18 \\
\hline Sorghum (3t/ha) & 3.72 & 2.42 & 0.40 & 0.18 & 1.18 & 0.14 \\
\hline Sorghum (6 t/ha) & 4.11 & 2.91 & 0.47 & 0.16 & 1.74 & 0.16 \\
\hline Cowpea (3 t/ha) & 3.75 & 2.45 & 0.24 & 0.15 & 1.74 & 0.17 \\
\hline Cowpea (6 t/ha) & 4.14 & 2.99 & 0.63 & 0.24 & 1.76 & 0.18 \\
\hline Groundnut (3t/ha) & 3.55 & 2.31 & 0.58 & 0.19 & 1.74 & 0.16 \\
\hline Groundnut (6 t/ha) & 3.62 & 2.14 & 0.60 & 0.21 & 1.75 & 0.17 \\
\hline \multicolumn{7}{|l|}{ Animal manures } \\
\hline Poultry (3 t/ha) & 3.90 & 2.66 & 0.46 & 0.22 & 1.73 & 0.16 \\
\hline Poultry (6 t/ha) & 4.66 & 3.42 & 0.48 & 0.25 & 1.81 & 0.19 \\
\hline Cattle (3 t/ha) & 3.22 & 1.98 & 0.24 & 0.17 & 1.72 & 0.14 \\
\hline Cattle (6 t/ha) & 4.28 & 3.13 & 0.30 & 0.24 & 1.79 & 0.18 \\
\hline P-value & 0.001 & 0.001 & 0.004 & 0.002 & 0.003 & 0.002 \\
\hline $\operatorname{LSD}(P \leq 0.05)$ & 0.33 & 0.22 & 0.42 & 0.07 & 0.10 & 0.02 \\
\hline
\end{tabular}

Note. WAE $=$ weeks after emergence; Control $=$ no fertilizer. 
Table $1 \mathrm{~b}$. Effect of combining poultry manure with crop residues on N, P and $\mathrm{K}$ contents of sesame leaves at 4 weeks after emergence and $75 \%$ flowering

\begin{tabular}{|c|c|c|c|c|c|c|}
\hline \multirow{2}{*}{ Treatments } & \multicolumn{2}{|c|}{ Nitrogen (\%) } & \multicolumn{2}{|c|}{ Phosphorus (\%) } & \multicolumn{2}{|c|}{ Potassium (\%) } \\
\hline & 4 WAE & 75\% Flowering & 4 WAE & 75\% Flowering & 4 WAE & 75\% Flowering \\
\hline Control & 3.44 & 2.14 & 0.31 & 0.14 & 1.65 & 0.13 \\
\hline \multicolumn{7}{|c|}{ Poultry manure + crop residues } \\
\hline PM + Millet (3 t/ha) & 3.53 & 2.33 & 0.39 & 0.25 & 1.77 & 0.16 \\
\hline PM + Millet (6 t/ha) & 4.84 & 3.61 & 0.66 & 0.26 & 1.86 & 0.19 \\
\hline PM + Sorghum $(3 \mathrm{t} / \mathrm{ha})$ & 2.43 & 1.19 & 0.50 & 0.20 & 1.73 & 0.17 \\
\hline $\mathrm{PM}+\operatorname{Sorghum}(6 \mathrm{t} / \mathrm{ha})$ & 3.89 & 2.66 & 0.55 & 0.23 & 1.75 & 0.19 \\
\hline PM + Cowpea (3 t/ha) & 4.02 & 2.31 & 0.55 & 0.18 & 1.75 & 0.16 \\
\hline PM + Cowpea $(6 \mathrm{t} / \mathrm{ha})$ & 4.29 & 2.96 & 0.60 & 0.27 & 1.79 & 0.19 \\
\hline PM + Gnuts (3 t/ha) & 3.70 & 2.19 & 0.55 & 0.15 & 1.71 & 0.17 \\
\hline PM + Gnuts (6 t/ha) & 4.18 & 2.38 & 0.59 & 0.21 & 1.72 & 0.16 \\
\hline P-value & 0.001 & 0.001 & 0.004 & 0.002 & 0.003 & 0.002 \\
\hline $\operatorname{LSD}(P \leq 0.05)$ & 0.33 & 0.22 & 0.42 & 0.07 & 0.10 & 0.02 \\
\hline
\end{tabular}

Note. $\mathrm{WAE}=$ weeks after emergence, $\mathrm{PM}=$ poultry manure, Control $=$ no amendment.

Table 1c. Effect of combining cattle manure with crop residues on $\mathrm{N}, \mathrm{P}$ and $\mathrm{K}$ contents of sesame leaves at 4 weeks after emergence and $75 \%$ flowering

\begin{tabular}{|c|c|c|c|c|c|c|}
\hline \multirow[b]{2}{*}{ Treatments } & \multicolumn{2}{|c|}{ Nitrogen (\%) } & \multicolumn{2}{|c|}{ Phosphorus (\%) } & \multicolumn{2}{|c|}{ Potassium (\%) } \\
\hline & $\begin{array}{l}4 \text { weeks after } \\
\text { emergence }\end{array}$ & 75\% Flowering & $\begin{array}{l}4 \text { weeks after } \\
\text { emergence }\end{array}$ & 75\% Flowering & $\begin{array}{l}4 \text { weeks after } \\
\text { emergence }\end{array}$ & 75\% Flowering \\
\hline Control & 3.44 & 2.14 & 0.31 & 0.14 & 1.65 & 0.13 \\
\hline \multicolumn{7}{|c|}{ Cattle manure + crop residues } \\
\hline Cattle + Millet $(3 \mathrm{t} / \mathrm{ha})$ & 3.76 & 2.33 & 0.25 & 0.19 & 1.63 & 0.15 \\
\hline Cattle + Millet $(6 \mathrm{t} / \mathrm{ha})$ & 4.08 & 3.51 & 0.27 & 0.26 & 1.77 & 0.19 \\
\hline Cattle + Sorghum $(3 \mathrm{t} / \mathrm{ha})$ & 3.03 & 1.69 & 0.23 & 0.20 & 1.73 & 0.13 \\
\hline Cattle + Sorghum $(6 \mathrm{t} / \mathrm{ha})$ & 3.65 & 2.22 & 0.24 & 0.18 & 1.74 & 0.15 \\
\hline Cattle + Cowpea $(3 \mathrm{t} / \mathrm{ha})$ & 3.51 & 2.26 & 0.25 & 0.20 & 1.70 & 0.15 \\
\hline Cattle + Cowpea (6 t/ha) & 4.04 & 2.83 & 0.27 & 0.24 & 1.76 & 0.18 \\
\hline Cattle + G.nuts (3 t/ha) & 3.47 & 2.22 & 0.22 & 0.15 & 1.66 & 0.12 \\
\hline Cattle + G.nuts $(6 \mathrm{t} / \mathrm{ha})$ & 3.75 & 2.30 & 0.26 & 0.21 & 1.75 & 0.15 \\
\hline P-value & 0.001 & 0.001 & 0.004 & 0.002 & 0.003 & 0.002 \\
\hline $\operatorname{LSD}(\mathrm{P} \leq 0.05)$ & 0.33 & 0.22 & 0.42 & 0.07 & 0.10 & 0.02 \\
\hline
\end{tabular}

Note. $\mathrm{WAE}=$ weeks after emergence, G.nuts $=$ groundnuts, Control $=$ no amendment.

\subsection{Effect of Crop Residues, Animal Manures and Their Combinations on Sesame Nutritional Seed Quality}

Applications of crop residues and animal manures singly and in combination had a significant $(\mathrm{P} \leq 0.05)$ effect on sesame seed crude protein $\%$, total ash $\%$ and oil content. Application of $6 \mathrm{t} / \mathrm{ha}$ of finger millet, cowpea and groundnut crop residues produced significantly $(\mathrm{P} \leq 0.05)$ higher sesame seed crude protein $\%$ ( 25.26 to $46.61 \%)$, total ash (4.26 to $7.68 \%)$ and oil content (65.65 to $69.29 \%)$, respectively, than the control and other crop residue treatments across seasons (Table 2a). Crop residues enhanced seed crude protein content in the order of finger millet $>$ cowpea $>$ groundnut $>$ sorghum, seed total ash in the order of cowpea $>$ finger millet $>$ groundnut $>$ sorghum and seed oil content in the order of groundnut $>$ sorghum $>$ cowpea $>$ finger millet (Table 2a). Poultry manure (6 t/ha) produced significantly $(\mathrm{P} \leq 0.05)$ higher sesame seed crude protein\% $(25.29$ to $31.78 \%)$ than the control, poultry manure ( $3 \mathrm{t} / \mathrm{ha}$ ) and cattle manure treatments across seasons (Table $2 \mathrm{a})$. Application of $3 \mathrm{t} / \mathrm{ha}$ of poultry manure produced significantly higher sesame seed total ash $(4.32$ to $8.851 \%)$ than $6 \mathrm{t} / \mathrm{ha}$ of poultry manure and cattle manure treatments (Table 2a). Application of $3 \mathrm{t} / \mathrm{ha}$ of cattle manure produced significantly ( $\mathrm{P}$ $\leq 0.05)$ higher sesame seed oil content $(63.54$ to $64.39 \%)$ than $6 \mathrm{t} / \mathrm{ha}$ of cattle manure and poultry manure ( 3 and $6 \mathrm{t} / \mathrm{ha})$ (Table 2a). Poultry manure plus finger millet husks $(6 \mathrm{t} / \mathrm{ha})$ produced significantly $(\mathrm{P} \leq 0.05)$ higher 
sesame seed crude protein $\%$ ( 26.35 to $48.23 \%$ ) and total ash\% (4.57 to $8.71 \%$ ) than $3 \mathrm{t} /$ ha of poultry manure plus finger millet husks and poultry manure plus other crop residues across seasons (Table 2b). Poultry manure plus groundnut shells $(3 \mathrm{t} / \mathrm{ha})$ produced significantly $(\mathrm{P} \leq 0.05)$ higher sesame seed oil content $(61.33$ to $67.95 \%)$ than $6 \mathrm{t} /$ ha of poultry manure plus groundnut shells and poultry manure plus other crop residues across seasons (Table $2 \mathrm{~b})$. Cattle manure plus groundnut shells $(6 \mathrm{t} / \mathrm{ha})$ produced significantly $(\mathrm{P} \leq 0.05)$ higher sesame seed crude protein\% (23.66 to31.02\%) and oil content (63.92 to 66.35\%) than cattle manure plus groundnut shells ( $3 \mathrm{t} / \mathrm{ha})$ and cattle manure plus other crop residues; while cattle manure plus sorghum husks $(6 \mathrm{t} / \mathrm{ha})$ produced significantly $(\mathrm{P} \leq 0.05)$ higher sesame seed total ash\% (4.53 to 7.23) than cattle manure plus other crop residues and cattle manure plus sorghum husks ( $3 \mathrm{t} / \mathrm{ha}$ ) (Table $2 \mathrm{c}$ ). Sesame seed crude protein and oil contents were higher in plots amended with crop residues than in plots amended with animal manure; while sesame seed total ash was higher in plots treated with animal manure than those treated with crop residues (Table 2a). Plots with combined applications of animal manure and crop residues produced higher sesame seed crude protein and seed total ash contents than plots amended with animal manure and crop residues singly (Tables $2 \mathrm{a}, 2 \mathrm{~b}$ and $2 \mathrm{c}$ ). In contrast, oil was highest in plots treated with groundnut shells compared to plots amended with a combination of crop residues and animal manure (Tables $2 \mathrm{a}, 2 \mathrm{~b}$ and $2 \mathrm{c}$ ). Overall, poultry manure plus finger millet husks $(6 \mathrm{t} / \mathrm{ha})$, poultry manure plus cowpea husks ( $6 \mathrm{t} / \mathrm{ha})$ and sorghum husks $(6 \mathrm{t} / \mathrm{ha})$ produced the highest sesame seed crude protein content, total ash and oil content, respectively, compared to other treatments across seasons (Tables 2a, $2 \mathrm{~b}$ and $2 \mathrm{c})$.

Table 2a. Effect of crop residues and animal manure on nutritional seed quality of sesame

\begin{tabular}{|c|c|c|c|c|c|c|c|c|c|}
\hline \multirow{2}{*}{ Treatments } & \multicolumn{3}{|c|}{ Crude protein (\%) } & \multicolumn{3}{|c|}{ Total ash (\%) } & \multicolumn{3}{|c|}{ Oil content $(\%)$} \\
\hline & 2013SR & 2014LR & 2014SR & 2013LR & 2014LR & 2014SR & 2013 SR & 2014LR & 2014 SR \\
\hline Control & 17.85 & 15.85 & 15.02 & 2.05 & 4.12 & 4.04 & 39.33 & 43.22 & 37.38 \\
\hline \multicolumn{10}{|l|}{ Crop residues } \\
\hline Millet (3 t/ha) & 24.12 & 12.95 & 36.92 & 3.67 & 3.67 & 6.48 & 52.69 & 56.58 & 52.30 \\
\hline Millet (6 t/ha) & 25.26 & 28.82 & 46.41 & 3.84 & 4.44 & 6.78 & 43.43 & 47.32 & 43.04 \\
\hline Sorghum (3t/ha) & 24.61 & 12.25 & 23.03 & 4.16 & 3.65 & 5.61 & 63.79 & 65.15 & 63.30 \\
\hline Sorghum (6t/ha) & 22.52 & 12.00 & 21.73 & 3.63 & 3.88 & 5.43 & 69.15 & 69.04 & 65.20 \\
\hline Cowpea (3 t/ha) & 24.95 & 14.75 & 31.00 & 3.64 & 4.16 & 6.88 & 55.30 & 59.19 & 54.16 \\
\hline Cowpea (6 t/ha) & 22.77 & 21.51 & 31.67 & 4.26 & 6.82 & 7.68 & 54.55 & 58.44 & 53.35 \\
\hline Groundnut (3t/ha) & 25.12 & 13.75 & 16.33 & 3.92 & 3.33 & 4.98 & 50.14 & 55.50 & 49.65 \\
\hline Groundnut ( $6 \mathrm{t} / \mathrm{ha})$ & 24.19 & 20.48 & 19.64 & 4.03 & 3.94 & 5.42 & 69.29 & 65.65 & 59.80 \\
\hline \multicolumn{10}{|l|}{ Animal manure } \\
\hline Poultry (3 t/ha) & 23.63 & 29.09 & 26.11 & 4.32 & 8.51 & 7.60 & 56.85 & 62.21 & 56.14 \\
\hline Poultry (6 t/ha) & 25.29 & 29.57 & 31.78 & 3.73 & 7.67 & 6.45 & 54.68 & 60.05 & 54.20 \\
\hline Cattle (3 t/ha) & 22.86 & 16.33 & 13.67 & 3.63 & 4.91 & 6.19 & 68.03 & 64.39 & 63.54 \\
\hline Cattle (6 t/ha) & 23.60 & 17.22 & 23.24 & 3.72 & 3.72 & 6.36 & 59.21 & 64.58 & 58.73 \\
\hline P-value & 0.001 & 0.001 & $\mathbf{0 . 0 3}$ & 0.001 & 0.025 & 0.001 & 0.001 & 0.001 & 0.002 \\
\hline $\operatorname{LSD}(P \leq 0.05)$ & 0.60 & 3.87 & 3.99 & 0.18 & 2.16 & 1.32 & 0.16 & 2.21 & 2.12 \\
\hline
\end{tabular}

Note. Control $=$ no amendment, Cattle $=$ cattle manure, Poultry $=$ poultry manure, $\mathrm{LR}=$ long rains, $\mathrm{SR}=$ short rains. 
Table $2 \mathrm{~b}$. Nutritional seed quality of sesame as influenced by a combination of poultry manure with crop residues

\begin{tabular}{|c|c|c|c|c|c|c|c|c|c|}
\hline \multirow{2}{*}{ Treatments } & \multicolumn{3}{|c|}{ Crude protein (\%) } & \multicolumn{3}{|c|}{ Total ash (\%) } & \multicolumn{3}{|c|}{ Oil content $(\%)$} \\
\hline & 2013 SR & 2014LR & 2014 SR & 2013SR & 2014 LR & 2014 SR & 2013 SR & 2014LR & $2014 \mathrm{SR}$ \\
\hline Control & $\mathbf{1 7 . 8 5}$ & 15.85 & 15.02 & 2.05 & 4.12 & 4.04 & 39.33 & 43.22 & 37.38 \\
\hline \multicolumn{10}{|c|}{ Poultry manure + crop residues } \\
\hline PM + Millet (3 t/ha) & 25.81 & 22.94 & 38.51 & 3.59 & 7.66 & 3.26 & 55.56 & 59.70 & 53.63 \\
\hline PM + Millet (6 t/ha) & 26.35 & 38.52 & 48.23 & 4.38 & 8.43 & 4.99 & 39.07 & 44.21 & 38.14 \\
\hline PM + Sorghum (3 t/ha) & 22.70 & 26.30 & 30.44 & 3.48 & 6.71 & 3.87 & 52.41 & 61.07 & 55.00 \\
\hline PM + Sorghum (6 t/ha) & 23.34 & 35.38 & 33.61 & 3.81 & 6.98 & 6.93 & 51.77 & 55.92 & 49.85 \\
\hline PM + Cowpea $(3 \mathrm{t} / \mathrm{ha})$ & 20.35 & 22.30 & 22.37 & 4.16 & 7.71 & 4.32 & 60.39 & 65.21 & 60.94 \\
\hline PM + Cowpea $(6$ t/ha $)$ & 28.05 & 35.55 & 34.75 & 4.57 & 8.71 & 6.86 & 39.36 & 44.28 & 39.28 \\
\hline $\mathrm{PM}+$ Groundnut $(3 \mathrm{t} / \mathrm{ha})$ & 23.86 & 24.47 & 24.98 & 3.50 & 4.95 & 3.20 & 61.33 & 67.95 & 67.88 \\
\hline $\mathrm{PM}+$ Groundnut $(6 \mathrm{t} / \mathrm{ha})$ & 24.71 & 41.00 & 25.52 & 4.01 & 5.16 & 3.53 & 56.08 & 59.96 & 55.69 \\
\hline P-value & 0.001 & 0.001 & 0.03 & 0.001 & 0.025 & 0.001 & 0.001 & 0.001 & 0.002 \\
\hline $\operatorname{LSD}(P \leq 0.05)$ & 0.60 & 3.87 & 3.99 & 0.18 & 2.16 & 1.32 & 0.16 & 2.21 & 2.12 \\
\hline
\end{tabular}

Note. $\mathrm{PM}=$ poultry manure, Control $=$ no amendment, $\mathrm{LR}=$ long rains, $\mathrm{SR}=$ short rains.

Table 2c. Nutritional seed quality of sesame as influenced by a combination of cattle manure with crop residues

\begin{tabular}{|c|c|c|c|c|c|c|c|c|c|}
\hline \multirow{2}{*}{ Treatments } & \multicolumn{3}{|c|}{ Crude protein (\%) } & \multicolumn{3}{|c|}{ Total ash (\%) } & \multicolumn{3}{|c|}{ Oil content (\%) } \\
\hline & 2013 SR & 2014LR & 2014LR & 2013 SR & 2014 LR & 2014SR & 2013SR & 2014LR & 2014SR \\
\hline Control & 17.85 & 15.85 & 15.02 & 2.05 & 4.12 & 4.04 & 39.33 & 43.22 & 37.38 \\
\hline \multicolumn{10}{|c|}{ Cattle manure + crop residues } \\
\hline Cattle + Millet $(3 \mathrm{t} / \mathrm{ha})$ & 22.35 & 17.17 & 15.50 & 3.62 & 6.84 & 4.59 & 52.41 & 57.78 & 51.92 \\
\hline Cattle + Millet $(6 \mathrm{t} / \mathrm{ha})$ & 23.67 & 28.49 & 29.18 & 4.19 & 6.97 & 6.34 & 58.25 & 62.39 & 56.32 \\
\hline Cattle + Sorghum $(3 \mathrm{t} / \mathrm{ha})$ & 22.91 & 17.91 & 17.67 & 3.94 & 7.09 & 5.29 & 39.58 & 46.55 & 48.70 \\
\hline Cattle + Sorghum $(6 \mathrm{t} / \mathrm{ha})$ & 23.52 & 23.18 & 19.13 & 4.53 & 7.23 & 6.74 & 59.16 & 63.04 & 58.77 \\
\hline Cattle + Cowpea $(3 \mathrm{t} / \mathrm{ha})$ & 23.61 & 21.36 & 19.32 & 3.28 & 6.70 & 3.99 & 61.57 & 65.81 & 61.33 \\
\hline Cattle + Cowpea $(6 \mathrm{t} / \mathrm{ha})$ & 23.43 & 19.73 & 24.38 & 3.25 & 6.80 & 3.55 & 57.19 & 62.55 & 57.33 \\
\hline Cattle + Groundnut $(3 \mathrm{t} / \mathrm{ha})$ & 23.60 & 19.84 & 23.79 & 3.61 & 6.92 & 4.81 & 63.92 & 66.35 & 64.53 \\
\hline Cattle + Groundnut $(6 \mathrm{t} / \mathrm{ha})$ & 23.66 & 30.15 & 31.02 & 3.82 & 6.39 & 3.57 & 54.58 & 59.36 & 54.34 \\
\hline P-value & 0.001 & 0.001 & $\mathbf{0 . 0 3}$ & 0.001 & 0.025 & 0.001 & 0.001 & 0.001 & 0.002 \\
\hline LSD $(P \leq 0.05)$ & 0.60 & 3.87 & 3.99 & 0.18 & 2.16 & 1.32 & 0.16 & 2.21 & 2.12 \\
\hline
\end{tabular}

Note . Control $=$ no amendment, Cattle $=$ cattle manure, $\mathrm{LR}=$ long rains, $\mathrm{SR}=$ short rains .

\section{Discussion}

\subsection{Effect of Crop Residues and Animal Manures on Levels of N, $P$ and $K$ in Sesame Leaves}

Application of $6 \mathrm{t} / \mathrm{ha}$ of finger millet husks, poultry manure and poultry manure plus finger millet husks significantly increased the concentrations of $\mathrm{N}, \mathrm{P}$ and $\mathrm{K}$ in sesame leaves at 4 weeks after emergence and at $75 \%$ flowering relative to other treatments. Lower $\mathrm{C} / \mathrm{N}$ ratios of finger millet husks and poultry manure than other treatments could have caused faster release of $\mathrm{N}, \mathrm{P}$ and $\mathrm{K}$ which increased uptake by sesame. In addition, finger millet husks and poultry manure had higher $\mathrm{N}, \mathrm{P}$ and $\mathrm{K}$ levels than other treatments, resulting in release of higher quantities of these nutrients upon decomposition. Ojo et al. (2015) reported increases in the levels of $\mathrm{P}$ and $\mathrm{N}$ in maize plant tissues due to incorporation of poultry manure into the soil. This was linked to high content of $\mathrm{N}$ and $P$ in poultry manure which are released upon its decomposition. Nahar et al. (2008) and Mandal et al. (2009) reported that organic manures incorporated into soil decompose and increase soil nutrient status thereby enhancing nutrient uptake by plants.

Incorporation of finger millet husks in soil produced a higher concentration of $\mathrm{P}$ in sesame leaves at $75 \%$ flowering than other treatments. Finger millet husks which had higher P content than most crop residues could have increased $\mathrm{P}$ levels in soil upon decomposition. Consequently, it caused higher uptake by sesame than other 
crop residues. In addition, less $\mathrm{P}$ is utilized by plants during flowering which could have caused its accumulation in leaves at $75 \%$ flowering. Grant et al. (2005) reported the presence of high content of $\mathrm{P}$ in plant tissues at flowering than at early stage of growth and its grain filling stage. This was attributed to less demand for it at flowering compared to early and grain filling stages of crops.

Cattle manure plus finger millet husks (6 t/ha) had significantly higher concentrations of $\mathrm{N}$ and $\mathrm{K}$ in sesame leaves at 4 weeks after emergence and at $75 \%$ flowering than cattle manure combined with other crop residues. This could be attributed to higher $\mathrm{N}$ and $\mathrm{K}$ in finger millet husks than in other crop residues. Incorporation of 6 t/ha of cattle manure plus finger millet husks could have added higher levels of $\mathrm{K}$ and $\mathrm{N}$ upon decomposition resulting in increased uptake. Ewulo et al. (2007) and Khaled et al. (2012) reported that combined application of organic manures enhanced uptake of N, P and K by plants and the level of each nutrient in plant tissues depended on its initial concentration in organic manure.

Sesame leaf N, P and K levels were lower at $75 \%$ flowering than at 4 weeks after emergence. This could be a consequence of their assimilation into reproductive structures. Mandal et al. (2009) reported that $\mathrm{N}$ and $\mathrm{P}$ decreased in plant tissues of wheat as the crop progressed towards flowering and seeding due to assimilation into reproductive structures. Across all treatments, $\mathrm{K}$ level in sesame leaves was significantly lower than the accepted range of $2 \%$ to $3 \%$ (Bonheure et al., 1992; Tandon, 1995). This suggests that $\mathrm{K}$ levels in the study site were not adequate to meet the plant requirement at flowering. In addition, it could be a consequence of $\mathrm{K}$ being utilized at a higher rate by enzymes involved in protein synthesis and carbohydrate metabolism. Jadav et al. (2010) reported decline of $\mathrm{K}$ in sesame tissues during its growth and associated it with the role of $\mathrm{K}$ in carbohydrate, protein and oil synthesis.

\subsection{Effect of Crop Residues and Animal Manure on Seed Crude Protein, Oil and Total Ash Content of Sesame}

Application of crop residues and animal manures produced significantly higher seed crude protein in sesame than the non-amended control. Crop residues and animal manure could have increased $\mathrm{N}$ levels in the soil upon decomposition which promoted protein synthesis in sesame seeds. Vayipuri et al. (2003) and Mohandoss (2001) reported increases in seed crude protein content of sesame due to application of poultry manure and rice husks. This was attributed to high levels of $\mathrm{N}$ in poultry manure and rice husks released into the soil upon their decomposition.

Incorporation of finger millet husks in soil had higher sesame seed crude protein content than other crop residues, while groundnut shells had higher seed oil content than other crop residues. Finger millet husks with high initial $\mathrm{N}(3.46 \%)$ and low $\mathrm{C} / \mathrm{N}$ ratio (10.45:1) may have decomposed and released faster higher amounts of $\mathrm{N}$ that promoted protein synthesis in sesame seeds. The groundnut shells with lower initial $\mathrm{N}(1.80 \%)$ and high $\mathrm{K}$ $(1.01 \%)$ could have released less $\mathrm{N}$ and high $\mathrm{K}$ into the soil upon decomposition resulting in enhanced carbohydrate metabolism in sesame plants that promoted oil synthesis in sesame seeds than other crop residues. Nanjundappa et al. (2001) and Ahmed (2015) reported that fertilizers with higher N levels promote protein synthesis but reduce oil synthesis. Incorporation of $6 \mathrm{t} / \mathrm{ha}$ of finger millet husks had higher sesame seed crude protein content than $3 \mathrm{t} / \mathrm{ha}$ of finger millet husks and other crop residues, while $3 \mathrm{t} / \mathrm{ha}$ of groundnut shells had higher seed oil contents than 6 t/ha of groundnut shells and other crop residues. It is likely that incorporation of 6 $\mathrm{t} / \mathrm{ha}$ of finger millet husks added excess $\mathrm{N}$ into soil upon decomposition which affected oil synthesis in sesame seeds than $3 \mathrm{t} / \mathrm{ha}$ of finger millet husks and other crop residues. In contrast, $3 \mathrm{t} / \mathrm{ha}$ of groundnut shells in soil could have added less $\mathrm{N}$ upon decomposition which favoured oil synthesis in sesame seeds. Munir et al. (2007) obtained higher crude protein and low oil content in sunflower seeds with application of high $\mathrm{N}$ fertilizers. This was attributed to the role of $\mathrm{N}$ in promoting protein synthesis, while its increase reduces oil synthesis. Mondal et al. (2001) obtained increased oil content in sesame seeds harvested from plots treated with fertilizers high in K. This was attributed to the role of $\mathrm{K}$ in promoting oil synthesis in sesame seeds. Incorporation of $6 \mathrm{t} / \mathrm{ha}$ of cowpea husks into the soil had significantly higher sesame seed total ash than other crop residues. Cowpea husks are relatively high in initial $\mathrm{P}(0.60 \%), \mathrm{K}(0.55 \%)$ and $\mathrm{Ca}(0.30 \%)$ and low in $\mathrm{C} / \mathrm{N}$ ratio $(10.94: 1)$ compared to other crop residues. Incorporation of $6 \mathrm{t} / \mathrm{ha}$ of cowpea husks into the soil may have readily released high quantities of $\mathrm{P}, \mathrm{K}$ and $\mathrm{Ca}$ that resulted in high uptake by sesame plants. Khaled et al. (2012) reported that application fertilizers with high mineral contents enhanced their uptake by crops. Crop residues enhanced sesame seed crude protein, oil and total ash content in the order of finger millet $>$ cowpea $>$ sorghum $>$ groundnut, groundnut $>$ sorghum $>$ cowpea $>$ finger millet and cowpea $>$ finger millet $>$ sorghum $>$ groundnut, respectively. This implies that seed crude protein, oil and total ash content require different crop residues with specific nutrient contents and composition. 
Incorporation of $6 \mathrm{t} / \mathrm{ha}$ of poultry manure in soil had significantly higher sesame seed crude protein and total ash content than cattle manure, while $3 \mathrm{t} / \mathrm{ha}$ of cattle manure had higher sesame seed oil content than $3 \mathrm{t} / \mathrm{ha}$ of poultry manure. This is most likely due to higher levels of initial $\mathrm{N}(4.44 \%), \mathrm{P}(1.02 \%)$ and $\mathrm{K}(1.13 \%)$ and $\mathrm{Ca}$ $(1.24 \%)$ in poultry manure than cattle manure. Poultry manure incorporated in soil could have decomposed and added high quantities of $\mathrm{N}$ that promoted protein synthesis. Vaiyapuri et al. (2003) and Haruna et al. (2012) reported that incorporation of poultry manure in soil at higher rates promoted protein synthesis in sesame seeds. In addition, poultry manure may have also released high quantities of $\mathrm{P}, \mathrm{K}$ and $\mathrm{Ca}$ which could have increased their high uptake by sesame plants. Mandal et al. (2009) reported that organic residues with high levels of minerals decompose and release into soil higher quantities of minerals which enhances their absorption by crops. Incorporation of $3 \mathrm{t} / \mathrm{ha}$ of cattle manure into the soil with low initial $\mathrm{N}(3.07 \%)$ and relatively high $\mathrm{K}(0.92 \%)$ added less $\mathrm{N}$ and high $\mathrm{K}$ levels that could have enhanced oil synthesis in sesame seeds. Mondal et al. (2001) reported that application of organic fertilizers low in $\mathrm{N}$ and high in $\mathrm{K}$ increased sesame seed oil content. They attributed this to the role of $\mathrm{K}$ in enhancing enzyme activity in carbohydrate metabolism which is essential for oil synthesis in sesame seeds.

Incorporation of $6 \mathrm{t} / \mathrm{ha}$ of poultry manure plus finger millet husks in soil had significantly higher sesame seed crude protein content than poultry manure combined with other crop residues. It is most likely that poultry manure and finger millet husks with high initial $\mathrm{N}(4.44 \%)$ and (3.46\%), respectively, decomposed and released higher quantities of $\mathrm{N}$ that promoted protein synthesis in sesame seeds than other treatments. Plots amended with $3 \mathrm{t} / \mathrm{ha}$ of poultry manure plus groundnut shells had higher sesame seed oil content than other treatments. This could be attributed to low initial $\mathrm{N}(1.80 \%)$ in groundnut shells and relatively high initial $\mathrm{K}$ in poultry manure $(1.13 \%)$ and groundnut shells (1.01\%) compared to other crop residues and cattle manure. Therefore, when the mixture was incorporated in soil, it may have decomposed and released relatively low $\mathrm{N}$ and high $\mathrm{K}$ that enhanced carbohydrate metabolism in sesame plants resulting in increased seed oil content. Rathke et al. (2005) reported that application of lower levels of $\mathrm{N}$ fertilizer significantly increased oil content of sunflower seeds; while Johnson et al. (2013) obtained increased levels of oil in Brassica carinata with low $\mathrm{N}$ fertilizer application. Both attributed this to enhanced carbohydrate metabolism in sesame. Plots amended with $6 \mathrm{t} / \mathrm{ha}$ of poultry manure plus cowpea husks produced significantly higher sesame seed total ash content than other treatments. This could be attributed to a variety of mineral elements and relatively higher initial P $(0.60 \%), \mathrm{K}(0.55 \%)$ and $\mathrm{Ca}(0.30 \%)$ in cowpea husks than other crop residues. Consequently, the mixture could have decomposed and released large quantities of N, P, K and $\mathrm{Ca}$ into the soil which may have enhanced their uptake by sesame plants. Vaiyapuri et al. (2003) and Mandal et al. (2009) reported that incorporation of poultry manure and other organic manures, high in minerals increased their levels in soil upon decomposition and this increased their plant uptake.

\section{Conclusion}

This study has shown that finger millet husks enhanced growth, seed yield and seed protein content of sesame relative to other crop residues and animal manure. Poultry manure produced higher growth, seed yield and crude protein content of sesame than cattle manure. This study has also revealed that poultry manure plus millet husks enhanced sesame growth, seed yield and seed protein content than crop residues and animal manure applied singly. Groundnut shells enhanced sesame seed oil content compared to other treatments.

\section{References}

Ahmed, A. M. M. (2015). Response of two sesame (Sesamum Indicum L.) cultivars to Nitrogen and phosphorus fertilization under rainfed conditions (Doctoral dissertation, UOFK).

Aniku, J. R. F. (2001). Soil classification and pedology. AL 631(676.1) MUK Vol I, 9970-02-243-1. Kampala, Uganda: Fountain Publishers.

Anyanga, W. O., \& Obong, Y. Y. (2001). Sesame (Sesamum indicum L.). In J. K. Mukiibi (Ed.), Agriculture in Uganda (Vol. 11, pp. 97-102).

Anyanga, W. O., Obong, Y., Busolo-Bulafu, C. M., Zude Erobot, C., Odul, C. S., Oumo, J. R., ... Elayu, M. (2003). A decade of sesame breeding in Uganda. Ugandan Journal of Agricultural Sciences, 8, 135-140.

AOAC. (1990). Methods of the Association of Official Analytical Chemists (15th ed.). Method No. 920.85. AOAC, Arlington, VA, USA.

Baydar, H., Maquard, R., \& Turgut, I. (1999). Pure line selection for improved yield, oil content, and fatty acid composition of different (Sesamum indicum L.). Plant Breeding, 118, 462-464. https://doi.org/10.1046/ j.1439-0523.1999.00414.x 
Bedigian, D. (2003). Evolution of sesame (Revisited): Domestication, diversity and prospects. Genetic Resources and Crop Evolution, 50, 779-787. https://doi.org/10.1023/A:1025029903549

Bedigian, D., \& van der Maesen, L. J. G. (2003). Slimy Leaves and Oily Seeds: Distribution and Use of Sesamum spp. and Ceratotheca sesamoides (Pedaliaceae) in Africa (pp. 271-274).

Bonheure, D., \& Wilson, C. K. (1992). Mineral nutrition and fertilizers. In K. C. Wilson, \& M. N. Clifford (Eds.), Tea cultivation to consumption (p. 606). Chapman and Hall, London. https://doi.org/10.1007/978-94-0112326-6 9

Craswell, E. T., \& Lefroy, R. D. B. (2001). The role and function of organic matter in tropical soils. Nutrition Cycling in Agroecosystems, 61, 7-18. https://doi.org/10.1023/A:1013656024633

Ewulo, B. S., Hassan, K. O., \& Ojeniyi, S. O. (2007). Comparative Effect of Cowdung Manure on Soil and Leaf Nutrient and Yield of Pepper. International Journal of Agricultural Research, 2, 1043-1048. https://doi.org/ 10.3923/ijar.2007.1043.1048

Grant, C., Bittman, S., Montreal, M., Plenchette, C., \& Morel, C. (2005). Soil and fertilizer phosphorus: Effects on plant P supply and mycorrhizal development. Canadian Journal of Plant Science, 85, 3-14. https://doi.org/10.4141/P03-182

Haruna, I. M., \& Abimiku, M. S. (2012). Yield of sesame (Sesamum indicum L.) as influenced by organic fertilizers in the southern Guinea savanna of Nigeria. Sustainable Agriculture Research, 1(1), 66-69. https://doi.org/10.5539/sar.v1n1p66

Ibeawuchi, I. I., Obiefuna, J. C., Ofor, M. O., Ihem, E. E., Nwosu, F. O., Nkwocha, V. I., .. Phelps, S. (2013). Effects of nitrogen fertilizer application on seed yield, $\mathrm{N}$ uptake, $\mathrm{N}$ use efficiency, and seed quality of Brassica carinata. Canadian Journal of Plant Science, 93(6), 1073-1081. https://doi.org/10.4141/ cjps2013-222

Jadav, D. P., Padamani, D. R., Polara, K. B., Parmar, K. B., \& Babaria, N. B. (2010). Effect of different level of sulphur and potassium on growth, yield and yield attributes of sesame (Sesamum Indicum L.). An Asian Journal of Soil Science, 5(1), 106-108.

Johnson, J. M. F., \& Russ, W. G. (2013). Calendula and camelina response to nitrogen fertility. Industrial Crops and Products, 43, 684-691. https://doi.org/10.1016/j.indcrop.2012.07.056

Khaled, A. S., Mona, G., El-Kader, A., \& Zeinab, M. K. (2012). Effect of soil amendments on soil fertility and sesame crop productivity under newly reclaimed soil conditions. Journal of Applied Sciences Research, 8(3), 1568-1575.

Mandal, A., Ashok, K. P., Singh, D., \& Rginald, M. (2009). Effects of long-term organic and chemical fertilization on N and P in wheat plants and in soil during crop growth. Agrochimica, Pisa, 53, 79-91.

Mehlich, A. (1984). Mehlich-3 soil test extractant: a modification of Mehlich-2 extractant. Commun. Soil Sci. Plant Anal., 15(12), 1409-1416. https://doi.org/10.1080/00103628409367568

Mohandoss, M. (2001). Effect of soil incorporation of paddy rice husk on the grow and yield parameters of sesame and on soil physique-chemical characteristics. Sesame and Safflower Newsletter, 16, 60-61.

Mondal, S. S., Pramani, C. K., \& Das, J. (2001). Effect of nitrogen and potassium on oil yield, nutrient uptake and soil fertility in soybean-sesame in inter cropping system. Indian Journal of Agricultural Science, 71(1), 44-46.

Morris, J. B. (2002). Food, industrial, nutraceutical, and pharmaceutical uses of sesame genetic resources. In J. Janick \& A. Whipkey (Eds.), Trends in new crops and new uses (pp. 153-156). ASHS Press, Arlington, VA.

Munir, M. A., Malik, M. A., \& Saleem, M. F. (2007). Impact of integration of crop manuring and nitrogen application on growth, yield and quality of spring planted sunflower (Helianthus annuus L.). Pakistan Journal of Botany, 39(2), 441-449.

Munyua, B., Orr, A., \& Okwadi, J. (2013). Open sesame: A value chain analysis of Sesame Marketing in Northern Uganda. Socioeconomics Discussion Paper Series (No. 6).

Murphy, B. W. (2015). Impact of soil organic matter on soil properties-A review with emphasis on Australian soils. Soil Research, 53(6), 605-635. https://doi.org/10.1071/SR14246

Nahar, Z., Mistry, K. K., Saha, A. K., \& Khaliq, Q. A. (2008). Response of nitrogen levels on yield of sesame (Sesamum indicum L). South Asian Association for Regional Cooperation Journal of Agriculture, 6(1), 1-7. 
Nanjundappa, G., Shivaraj, B., Janarjuna, S., \& Sridhara, S. (2001). Effect of organic and inorganic sources of nutrients applied alone or in combination on growth and yield of sunlower (Helianthus annuus L.). Helia, 24(34), 115-120.

Nelson, D. W., \& Sommers, L. E. (2010). Methods of Soil Analysis. Retrieved November 15, 2010, from http://www.aaslpsu.edu/soils.methods.htm

Ojo, A. O., Adetunji, M. T., Okeleye, K. A., \& Adejuyigbe, C. O. (2015). Soil fertility, phosphorus fractions, and maize yield as affected by poultry manure and single superphosphate. International Scholarly Research Notices, 2015, 8. https://doi.org/10.1155/2015/616213

Rathke, G. W., Christen, O., \& Diepenbrock, W. (2005). Effects of nitrogen source and rate on productivity and quality of winter oilseed rape (Brassica napus L.) grown in different crop rotations. Field Crop Research, 94, 103-113. https://doi.org/10.1016/j.fcr.2004.11.010

Tandon, H. L. S. (1995). Methods and analysis of soils, plants, water and fertilizers (pp. 54-96). Fertilizer Development and Consultations Organization, New Delhi, India.

Tenywa, J. S., Kidoido, M., Nyende, P., Kasenge, V., Oryokot, J., \& Mbowa, S. (1999). Prospects and constraints of finger millet production in Eastern Uganda. African Crop Science Journal, 7, 563-578. https://doi.org/ 10.4314/acsj.v7i4.27751

Vaiyapuri, V., Amudha, A., Sriramchandrasekharan, M. V., \& Ravichandran, M. (2003). Effect of S levels and organics on seed quality and nutrient uptake of sesame. Res. on Crops, 4(3), 327-330.

\section{Copyrights}

Copyright for this article is retained by the author(s), with first publication rights granted to the journal.

This is an open-access article distributed under the terms and conditions of the Creative Commons Attribution license (http://creativecommons.org/licenses/by/4.0/). 